\title{
Market Games In Finance Education
}

\author{
F. Douglas Foster, University of NSW, Australia \\ Shirley Gregor, Australian National University, Australia \\ Richard Heaney, (E-mail: richard.heaney@rmit.edu.au), RMIT University, Australia \\ Terry O’Neill, Australian National University, Australia \\ Alex Richardson, Australian National University, Australia \\ Robert Wood, Australian Graduate School of Management, Australia
}

\begin{abstract}
An electronic share market trading game was introduced to a large first year undergraduate finance course to allow students to experience share market trading. The response from students was positive. We surveyed a sample of 51 of the students in this class who undertook a further one-hour trading session as part of a separate research experiment. These students rate the game as a valuable learning experience. They suggest that their use of the game increased their understanding of share market and the way that prices are set. While the study results cannot be generalised to all students in the course, the results suggest that there are benefits to be gained from including an electronic share market trading game as part of the course.
\end{abstract}

\section{Introduction}

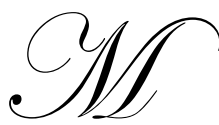

ost undergraduate finance courses offered at the university level focus on developing a theoretical framework. The educational experience is largely lecture and tutorial based but these approaches do not suit all areas of study. This is somewhat unique relative to other disciplines where the education may include laboratory sessions, performances, and a range of non-lecture experiences for students. Further, as financial markets move from the trading pit, or trading floor, to electronic trading systems there is need for students to gain an understanding of how these new markets work. Electronic share market games of the type discussed in this paper provide experience in the operation of modern trading systems. They also allow students to benefit potentially from experiential learning early in the curriculum.

The trading game used in this study uses a trading screen very much like the limit order trading screens found in modern electronic financial security trading systems so students that play the game can examine the price setting process as it occurs. They also gain experience in the process of buying and selling shares and the market terminology associated with this process.

Ball and Holt (1998), Sachdeva (1989), Frank (1997), Helliar, Michaelson, Power and Sinclair (2000) and Kagan, Mayo and Stout (1995) cite the benefits to be obtained from the use of games in a classroom situation. Our study shows that it is possible to set up reasonably life-like electronic trading system in a classroom at fairly low cost and using quite stable software. The participants in this study were drawn from a large undergraduate financial markets course where a share market trading game was introduced as part of the curriculum. In responses to survey questions we find that the students believed that the game added to their educational experience. It gave them an introduction into how an electronic limit order share trading system works as well as showing, in a very practical way, what drives bid and ask prices and how prices are actually set in the market. The students viewed this game as a positive learning experience.

A brief discussion of the teaching problem and the educational goals associated with the game are provided in the next section. A more complete description of the game is provided in Section 3, discussion of the survey results is provided in section 4 , with conclusions reported in section 5 . 


\section{Teaching problem and educational goals}

Bryant and Hunton (2000) provide an extensive survey of educational technology research. They argue that there is a relation between media attributes and learner attributes and that these interactions are important in the application of technology in teaching. It is often argued that the best media should provide two-way interaction with the user, though the literature suggests that student attributes can also have an important impact on the successful use of technology in a teaching environment. For example cognitive theory suggests that prior knowledge, motivation, mental effort and individual learning styles have an impact on the effectiveness of media in learning. We argue that trading on a share market game is very much an interactive process with the student deciding on a strategy and then setting this in place through their trading behaviour. Feedback on performance is rapid through the movement in share price and accumulation of profits or losses on trading. To some extent this survey provides an attempt to identify learner attributes and to see whether these attributes had an adverse impact on the level of student learning obtained from taking part in the game. There is a substantial literature verifying the appropriateness of the use of simulations in education. Wood and Bailey (1985) discuss the greater levels of realism that simulations provide students though they also indicate that there are some costs. For example, the instructor generally has less control over what is happening in a simulation yet this sort of activity tends to encourage deeper learning (Ramsden, 2000). Further, simulations are often costly to run.

Very few undergraduate programs cover the fundamentals of share market trading in early courses. Inevitably the early financial markets courses describe the markets and the securities traded on the markets with little discussion of how the markets work. There are often physical limitations on what can be achieved. The large size of first year undergraduate financial markets classes, often exceeding 500 students, and the volume of material that is regarded as required, limit what can be done with market games. Thus if an electronic trading game is to be used it must be fairly low cost and reasonably easy to use in order for the activity to be built into a standard tutorial and linked back to lectures.

Further, many educational share trading systems have students trading "paper" portfolios where they invest a certain sum in listed companies and hold their positions for relatively short periods of time (a few weeks). While these systems encourage students to learn about actual companies and acquaints them with a range of data sources, etc. they do not give a class the experience of managing liquidity (i.e. their trades do not affect the share market). For the added reality of using listed companies, students are expected to act as price takers. It is possible, however, to arrange a simulated share market, using fictional securities, where students must set prices, both supplying and demanding liquidity. The choice of which simulation is appropriate depends on the educational goal of the instructor, but it is important to note that each delivers different insights.

The concepts underlying limit order trading systems appear to be quite simple and it is often assumed that these issues may be cost/effectively treated within the standard chalk and talk paradigm found in most large undergraduate classes. Yet, it is surprising how often students fail to grasp what a bid price or an ask price is (as demonstrated in pilot training studies that were conducted as part of our experiment.). A share market trading game can improve student understanding of the concepts and practices inherent in trading on these systems.

There are two educational goals in our application of a share trading game. The first is to provide students with experience in trading with an electronic trading system. The second goal is to encourage students to understand the impact of asset value on traded price and to be aware that it is possible to glean information from traded prices. The first goal is technically ambitious because of the complexity of the software and hardware that is required to support such a market. This goal is now achievable with the availability of financial market trading game software that is stable and not too costly. Once the technical difficulties are overcome the experience of trading in such a market quickly shows the student how shares may be bought and sold and how prices are set in limit order markets. They learn these concepts by actually trading amongst themselves and this can provide important insights into the way that these markets work.

The second goal is particularly important. Students need to understand how prices come to reflect information and simple share market trading games that build information uncertainty into trading provide a graphic 
example of how pricing eventually reflects available information even though individual traders do not have full information. The simple information allocation algorithm used in our share market trading game provides an interesting information uncertainty problem. It is not unlike the problem that traders face, with access to up-to-date share prices as well as incomplete private information.

\section{The share trading game}

There are various examples of share market games being used for education purposes over the last 30 years or so (Frank, 1997 and Sachdeva, 1989) though the games often fall into the categories of either valuation based games (Ball and Holt, 1998) or portfolio construction based games (Helliar, Michaelson, Power and Sinclair, 2000, Kagan, Mayo and Stout, 1995). To date there is little written on the use of share market trading games that attempt to replicate trading conditions in an electronic limit order share market. We use a computer trading game called Financial Trading System, FTS, described in O'Brien and Srivastava $(1991)^{1}$ to provide students with trading experience in a simple market environment.

The "market efficiency" game used in this study is the simplest of a comprehensive set of market games supplied by OS Financial Trading Systems. We use only two shares throughout the study, although the software can deal with more shares. There are few limitations on the number of participants though hardware constraints will ultimately have an impact on the performance. For example, there were 57 participants in our study and this number of participants had little impact on the performance of the system.

Trading occurs over two periods and the assets pay a dividend at the end of each trading period with the security dividend schemes described in more detail in Appendix 1. While there is a facility for discounting we set the discount rate to zero for simplicity and so share value is simply equal to the sum of the expected dividend payments. Market participants have limited information about the dividend payments and so they must use the information given to them as well as the information provided in the reported share prices to determine the actual value of the shares. For example it is possible that the participant might receive the information that the dividend in period 1 is not $X$ and the dividend in period 2 is also not $X$. If this information is received for the share, $A B C$, then $\mathrm{ABC}$ must take on some value greater than zero. If this hint is provided for CRA then at the beginning of the game the participant knows that CRA will take a value of either $8,12,18,20,24,30,32,36$ or 42 , each with a probability of 1/9. This is a difficult valuation question for each individual though the individual can work out the expected value of 24.7. At the beginning of the second period there is a 1/3 probability of receiving 8,12 or 18 with expected value of 12.7. Each of the participants in the market receives similar levels of incomplete information with sufficient information made available to the market as a whole to identify exactly what the value of the share is.

We chose a trading period of about one hour, split into 10-minute trials, with each trial consisting of two 5minute trading periods, period 1 and period 2. There were usually about four to five trials in a one-hour trading session. At the beginning of the game the participants are allocated cash and securities though the split between these two asset categories varies across the individuals. They are also given incomplete information on the dividends that are to be paid at the end of each of the two trading periods. Once trading begins the participants flag their wish to buy or sell securities by entering a bid or ask price or they might choose to accept existing ask or bid prices. $^{2}$

A copy of the trading screen is provided in Figure 1. The key features of the game are apparent in this screen dump, including the facility to enter bid and ask price and quantity as well as disclosure of other important information about the game such as the current bid and ask prices and the current position of the participant in each of the two stocks, ABC and CRA. The two securities may pay dividends at the end of period 1 and period 2 and the central white rectangle contains the participant's information about the dividends that the shares will pay.

The time left, upper left corner, is a critical piece of information as it informs the participants of when the market is trading and how much time remains in the present trading period. In the experiment, though not in the course based tutorials, the nominal fee paid to each participant consisted of a fixed component and a variable component based on trading. At the end of each trial each participant's performance was compared with a randomly 
drawn benchmark and compensation was paid where performance exceeded the benchmark. Thus in the experiment the participants were encouraged to maximise trading profit in each trial.

Figure 1 - Screen dump for the trading screen

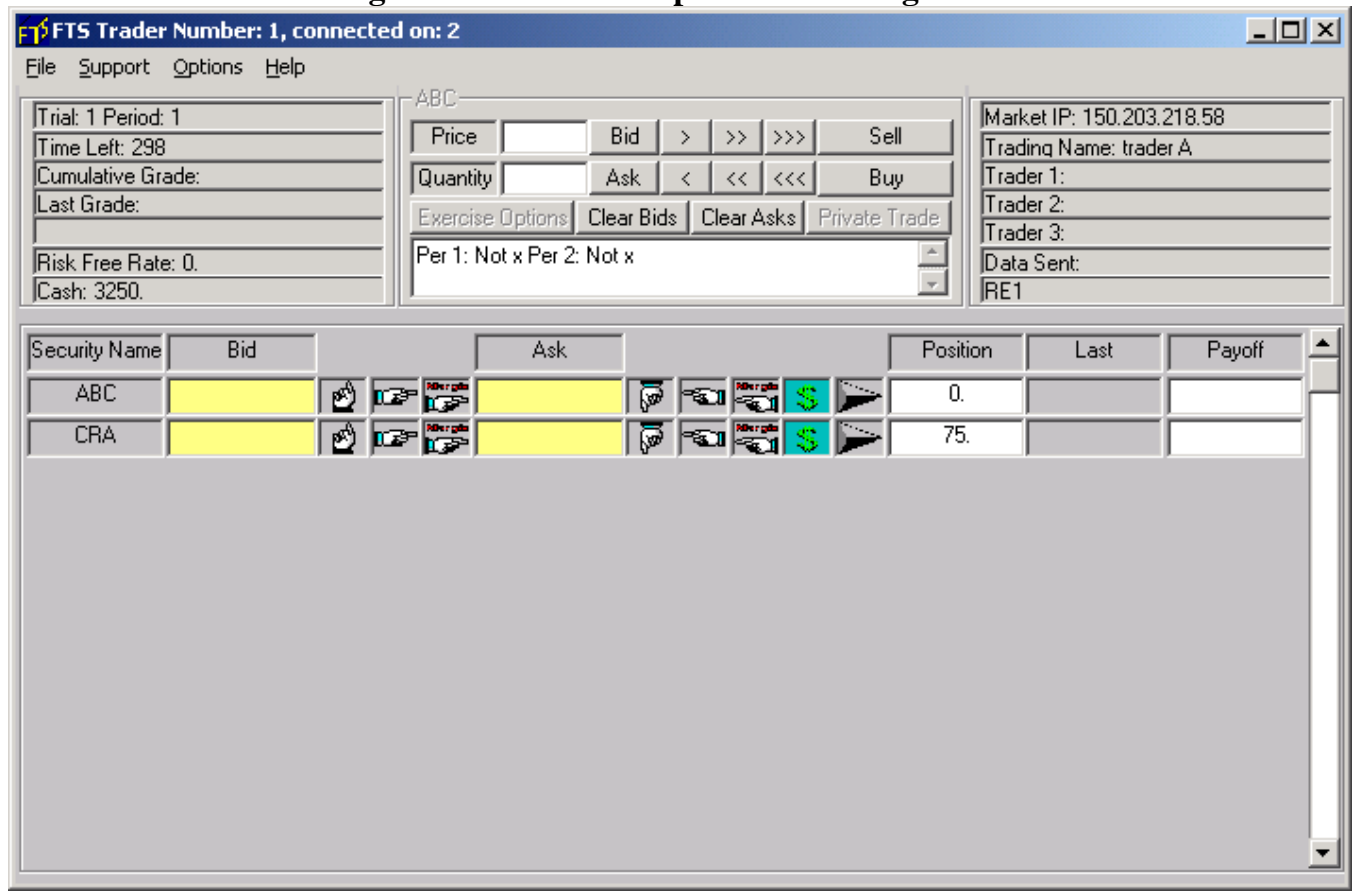

\section{Student Evaluation}

All students in the undergraduate course were required to complete a one-hour tutorial share market trading session that formed part of the course. The final group used in this study agreed to take part in a further trading period which forms part of a more extensive two hour research experiment dealing with various aspects of individual trading behaviour in electronic share markets. They were volunteers and, as discussed above, they were also paid a nominal fee designed to encourage profit maximisation in the second of the two trading sessions. As a result some care should be taken with generalisation of the results of this survey, though the sample did amount to around $10 \%$ of the class. The survey-based data reported here was gathered after the first of two hours of trading.

Fifty-seven undergraduate students participated in the study with fifty-one completing the questionnaire. The questionnaire (Appendix 2) included four background questions dealing with age, gender, first language and previous experience with share market trading. While the participant gender was split fairly evenly with $59 \%$ male and $41 \%$ female, around two thirds of the participants indicated that English was not their first language. Further, $86 \%$ of the sample indicates that they had not traded in shares before. This suggests that learning about trading mechanisms is not something that they are achieving outside of their courses.

The remainder of the study instrument contains questions concerned with how confident the participants were about using the trading game and what level of understanding they believe that they developed through their exposure to the trading game. There were also two open-ended questions that allowed students to comment on the use of the trading game and on the strategies that they use in trading though we do not discuss the open-ended comments further here. The open-ended strategy questions were followed by a series of more specific questions dealing with the strategies that the students adopted in their trading. 
Table 1 - Descriptive Statistics

\begin{tabular}{|c|c|c|c|c|c|}
\hline & Mean & Median & Std. dev. & Count & $\begin{array}{c}\text { Chi- } \\
\text { square } \\
\text { test prob. }\end{array}$ \\
\hline Age in years & 20.12 & 20.00 & 1.70 & 51 & \\
\hline \multicolumn{6}{|l|}{ Confidence in trading with the trading game } \\
\hline 5a, Pricing a share & 3.37 & 3.00 & 0.91 & 49.00 & 0.00 \\
\hline $5 b$, Setting a bid & 3.48 & 3.00 & 1.15 & 50.00 & 0.01 \\
\hline $5 c$, Setting an ask & 3.36 & 3.00 & 1.26 & 50.00 & 0.07 \\
\hline $5 \mathrm{~d}$, Buying & 3.57 & 3.00 & 1.06 & 51.00 & 0.00 \\
\hline 5e, Selling & 3.69 & 4.00 & 1.03 & 51.00 & 0.00 \\
\hline \multicolumn{6}{|l|}{ Experience evaluation } \\
\hline $\begin{array}{l}\text { 6a, The FTS game increased my understanding of } \\
\text { financial trading. }\end{array}$ & 3.73 & 4.00 & 1.02 & 51.00 & 0.00 \\
\hline $\begin{array}{l}\text { 6b, The FTS game helped me understand the } \\
\text { different decisions needed for financial trading. }\end{array}$ & 3.67 & 4.00 & 0.95 & 51.00 & 0.00 \\
\hline $\begin{array}{l}\text { 6c, After the FTS game, I was more satisfied with } \\
\text { my understanding of how to trade stocks. }\end{array}$ & 3.41 & 3.00 & 0.98 & 51.00 & 0.00 \\
\hline $\begin{array}{l}\text { 6d, The FTS game gave me practical knowledge of } \\
\text { material taught in FINM001. }\end{array}$ & 2.86 & 3.00 & 1.11 & 51.00 & 0.09 \\
\hline $\begin{array}{l}\text { 6e, Overall, I was satisfied with the experience with } \\
\text { the FTS game. }\end{array}$ & 3.80 & 4.00 & 0.83 & 51.00 & 0.00 \\
\hline \multicolumn{6}{|l|}{ Strategies } \\
\hline $\begin{array}{l}\text { 9a, I spent most of my time trying to maximize my } \\
\text { earnings }\end{array}$ & 4.05 & 4.00 & 1.03 & 44.00 & 0.00 \\
\hline $\begin{array}{l}9 \mathrm{~b}, \mathrm{I} \text { tried to make money through differences in the } \\
\text { bid and the ask prices. }\end{array}$ & 3.71 & 4.00 & 1.18 & 45.00 & 0.00 \\
\hline $\begin{array}{l}\text { 9c, I tried to make money through differences in the } \\
\text { current price of a share and my forecast of future } \\
\text { earnings. }\end{array}$ & 3.30 & 3.00 & 1.23 & 44.00 & 0.22 \\
\hline $\begin{array}{l}\text { 9d, I spent most of my time trying to minimize or } \\
\text { avoid losses. }\end{array}$ & 2.84 & 3.00 & 1.31 & 43.00 & 0.30 \\
\hline 9e, I mostly followed a buy and hold strategy. & 2.76 & 3.00 & 1.22 & 41.00 & 0.48 \\
\hline $\begin{array}{l}\text { 9f, I was a very active trader and made a lot of } \\
\text { trades in most periods }\end{array}$ & 3.11 & 3.00 & 1.15 & 44.00 & 0.38 \\
\hline $\begin{array}{l}9 \mathrm{~g}, \text { I changed my strategies a lot across the different } \\
\text { periods. }\end{array}$ & 2.77 & 3.00 & 1.41 & 44.00 & 0.37 \\
\hline
\end{tabular}

Notes: * significant at the 5\% level of significance. The 'not sure' responses were set to missing values for the calculation of descriptive statistics and the tests assume a null of 'moderately confident' in the questions concerning confidence, 'neither agree nor disagree' in the questions dealing with the experience evaluation and 'moderately accurate' for the strategy questions. The chi-square probability is based on a comparison of the number of participants that selected either one or two versus the number of participants that selected either three or four. The expected number in each case, the number of $1 \mathrm{~s}$ or $2 \mathrm{~s}$ and the number of $4 \mathrm{~s}$ or $5 \mathrm{~s}$, is defined as two fifths of the number of participants that answered the question $\left(2 / 5^{*} \mathrm{~N}\right)$. 
Table 2 - Proportion of Responses By Question

\begin{tabular}{|c|c|c|c|c|c|c|}
\hline Response & 1 & 2 & 3 & 4 & 5 & Not sure \\
\hline \multicolumn{7}{|l|}{$\begin{array}{l}\text { Confidence in trading with the trading } \\
\text { game }\end{array}$} \\
\hline 5a, Pricing a share & 0.02 & 0.08 & 0.53 & 0.20 & 0.14 & 0.04 \\
\hline $5 b$, Setting a bid & 0.06 & 0.10 & 0.37 & 0.22 & 0.24 & 0.02 \\
\hline $5 c$, Setting an ask & 0.08 & 0.16 & 0.33 & 0.16 & 0.25 & 0.02 \\
\hline 5d, Buying & 0.02 & 0.10 & 0.45 & 0.16 & 0.27 & 0.00 \\
\hline 5e, Selling & 0.02 & 0.08 & 0.37 & 0.25 & 0.27 & 0.00 \\
\hline \multicolumn{7}{|l|}{ Experience evaluation } \\
\hline $\begin{array}{l}\text { 6a, The FTS game increased my } \\
\text { understanding of financial trading. }\end{array}$ & 0.04 & 0.08 & 0.22 & 0.45 & 0.22 & 0.00 \\
\hline $\begin{array}{l}\text { 6b, The FTS game helped me understand } \\
\text { the different decisions needed for } \\
\text { financial trading. }\end{array}$ & 0.04 & 0.06 & 0.25 & 0.49 & 0.16 & 0.00 \\
\hline $\begin{array}{l}\text { 6c, After the FTS game, I was more satisfied } \\
\text { with my understanding of how to trade } \\
\text { stocks. }\end{array}$ & 0.04 & 0.12 & 0.35 & 0.37 & 0.12 & 0.00 \\
\hline $\begin{array}{l}\text { 6d, The FTS game gave me practical } \\
\text { knowledge of material taught in } \\
\text { FINM001. }\end{array}$ & 0.16 & 0.16 & 0.41 & 0.22 & 0.06 & 0.00 \\
\hline $\begin{array}{l}\text { 6e, Overall, I was satisfied with the } \\
\text { experience with the FTS game. }\end{array}$ & 0.02 & 0.04 & 0.22 & 0.57 & 0.16 & 0.00 \\
\hline \multicolumn{7}{|l|}{ Strategies } \\
\hline $\begin{array}{l}9 \mathrm{a}, \text { I spent most of my time trying to } \\
\text { maximize my earnings }\end{array}$ & 0.04 & 0.00 & 0.20 & 0.27 & 0.35 & 0.14 \\
\hline $\begin{array}{l}9 \mathrm{~b}, \text { I tried to make money through } \\
\text { differences in the bid and the ask prices. }\end{array}$ & 0.06 & 0.06 & 0.24 & 0.25 & 0.27 & 0.12 \\
\hline $\begin{array}{l}9 \mathrm{c}, \mathrm{I} \text { tried to make money through differences } \\
\text { in the current price of a share and my } \\
\text { forecast of future earnings. }\end{array}$ & 0.06 & 0.20 & 0.22 & 0.22 & 0.18 & 0.14 \\
\hline $\begin{array}{l}\text { 9d, I spent most of my time trying to } \\
\text { minimize or avoid losses. }\end{array}$ & 0.16 & 0.20 & 0.24 & 0.14 & 0.12 & 0.16 \\
\hline $\begin{array}{l}\text { 9e, I mostly followed a buy and hold } \\
\text { strategy. }\end{array}$ & 0.16 & 0.20 & 0.18 & 0.24 & 0.04 & 0.20 \\
\hline $\begin{array}{l}\text { 9f, I was a very active trader and made a lot } \\
\text { of trades in most periods }\end{array}$ & 0.04 & 0.25 & 0.27 & 0.16 & 0.14 & 0.14 \\
\hline $\begin{array}{l}9 \mathrm{~g}, \text { I changed my strategies a lot across the } \\
\text { different periods. }\end{array}$ & 0.22 & 0.20 & 0.14 & 0.20 & 0.12 & 0.14 \\
\hline
\end{tabular}

Table 1 provides a set of descriptive statistics as well as statistical tests for each of the questions in the evaluation survey while the actual proportions of the group responses allocated to each code are reported in Table 2 . The 'not sure' responses are a special category; we set these to missing values for the calculation of descriptive statistics. In an attempt to assess the strength of responses to the questions we use chi-square tests to test whether we can reject the null that the selection of high $(4,5)$ or low $(1,2)$ values are equally likely. The chi-square tests assume a null of 'moderately confident' in the questions concerning confidence, 'neither agree nor disagree' in the questions dealing with the experience evaluation and 'moderately accurate' for the strategy questions. ${ }^{3}$ As is apparent from Table 2, the majority of the sample indicates that they are moderately confident about their ability to 
undertake the bid, ask, buy and sell transactions after they had completed the game. Further, in Table 2 the chisquare tests suggest that there was a greater share of the sample that were totally confident relative to those who expressed a lack of confidence in their trading ability. This is an important finding as students often have some difficulty with understanding what these terms mean when they learn them in the traditional lecture/tutorial forum. Further, in the FTS experience evaluation questions there is evidence that the participants agreed that they gained increased understanding about trading and they feel that the overall experience is a positive one with the majority of the responses in the 3 to 4 range.

One interesting response concerns the link between class work and the game. The students were generally neutral towards this, suggesting that the share market game gave the students access to material that was not otherwise provided in the course. Given that this is a financial markets course, this is an important finding because it suggests that stronger links might be constructed in the future between the course material and the trading game. This was the first time that the share market trading game had been used in a first year undergraduate course and it is expected that there would be further fine-tuning of the course, the share market trading game and the linkage between the two in the future.

The final set of questions focus on strategy. The responses are consistent with the payment scheme. Participants strongly favoured either maximising earnings or providing liquidity by focusing on the bid/ask spread as their trading strategy. Both of these schemes seem to support a rational attempt to maximise the nominal payment that they receive from taking part in the game. There is no evidence of statistically significant rejection of the remaining strategy based questions with most participants identifying the strategy as describing their strategy in a moderately accurate way. The chi-square statistics suggest that the remaining responses were evenly distributed between totally accurate and not at all accurate.

\section{Conclusion}

Although these results can only be generalised with caution, due to the nature of the sample, it would appear that a considerable proportion of the students in this first year course believe that they benefited from the inclusion of a share trading game in this first year finance course. Some of the major factors to come out of the study include the positive attitude of students towards the use of the game and the feeling that they had learned something from the experience. The lack of strong beliefs about strategies is interesting though the strong results on the strategies of maximising earnings and the focus on bid and ask prices is consistent with the trading profit based payments that were made to participants as part of the study.

\section{References}

1. Ball, S. B. and Holt, C. A., 1998 "Classroom Games: Speculation and Bubbles in an Asset Market", Journal of Economic Perspectives, 12, 207-218.

2. Bryant, S., M. and Hunton, J. E., 2000 "The Use of Technology in the Delivery of Instruction: Implications for Accounting Educators and Education Researchers", Issues in Accounting Education, 15, 129-162.

3. Frank, B., 1997 "The Impact of Classroom Experiments on the Learning of Economics: An Empirical Investigation”, Economic Inquiry, 35, 763-769.

4. Helliar, C.V., Michaelson, R., Power, D.M. and Sinclair, C.D., 2000. "Using a Portfolio Management Game (Finesse) to Teach Finance", Accounting Education, 9, 37-51.

5. Kagan, G., Mayo, H. and Stout, R., 1995 "Risk-Adjusted Returns and Stock Market Games", Journal of Economic Education, 26, 39-50.

6. O'Brien, J. and Srivastava, S., 1991 "Dynamic Stock Markets With Multiple Assets: An Experimental Analysis," Journal of Finance, 46, 1811-1838.

7. Ramsden, P., 2000, Learning to Teach in Higher Education, Routledge, New York.

8. Sachdeva, D., 1989 "Psychology of Computer Use: XI. Students' Attitudes Toward Use of ComputerSimulation Games in Teaching Business Finance", Psychological Reports, 64, 1195-1198.

9. Wood, R. E. and Bailey, T. S., 1985 "Some Unanswered Questions about Goal Effects: A Recommended Change in Research Methods", Australian Journal of Management, 10, 61-76. 


\section{Endnotes}

1 OS Financial Trading Systems, P.O. Box 11356 Pittsburgh. P.A. 15238, 1800967 9897, email address: fts@ftsweb.com, web address: www.ftsweb.com.

2 It is also possible to short sell securities and to borrow to fund purchases.

3 This approach to testing is similar to that used in Helliar, Michaelson, Power, and Sinclair (2000).

\section{Appendix 1 - Dividend determination}

There are two trading periods and the dividend payments are paid at the end of the two trading periods. Participants do not have full information concerning the dividend payments but instead each participant is given partial information about the dividend payment occurring at the end of period 1 and period 2. The following table describes the equally likely events affecting each firm, and the dividends paid at the end of period 1.

\begin{tabular}{llc}
\hline Firm ABC & & Dividend \\
\hline Event x & Poor economic conditions, labour strike & 0 \\
Event y & Poor economic conditions, no strike & 12 \\
Event z & Fair economic conditions, good labour relations & 24 \\
Firm CRA & & Dividend \\
Event w & Poor economic conditions, labour strike & 0 \\
Event x & Poor economic conditions, no strike & 12 \\
Event y & Fair economic conditions, no strike & 12 \\
Event $\mathrm{z}$ & Fair economic conditions, good labour relations & 24 \\
\hline \multicolumn{2}{l}{ The dividends paid at the end of period 2 depend on both the period 1 event and the period 2 event. }
\end{tabular}

Firm ABC

\begin{tabular}{|c|c|c|c|}
\hline Period 1 Event & Peric & Event & \\
\hline $\begin{array}{l}\text { Per2 Col/Per } 1 \\
\text { Row }\end{array}$ & $\mathrm{x}$ & $\mathrm{y}$ & $\mathrm{Z}$ \\
\hline $\mathrm{x}$ & 0,0 & 0,0 & 0,12 \\
\hline $\mathrm{y}$ & 12,0 & 12,12 & 12,24 \\
\hline $\mathrm{z}$ & 24,12 & 24,12 & 24,24 \\
\hline
\end{tabular}

\begin{tabular}{lcccc} 
Firm CRA & \multicolumn{7}{l}{} \\
\hline Period 1 Event & \multicolumn{7}{l}{ Period 2 Event } & & \\
\hline Per 2 Col/Per 1 & $\mathrm{W}$ & $\mathrm{X}$ & $\mathrm{Y}$ & $\mathrm{Z}$ \\
Row & & & & \\
$\mathrm{W}$ & 0,8 & 0,8 & 0,12 & 0,18 \\
$\mathrm{X}$ & 12,8 & 12,8 & 12,12 & 12,18 \\
$\mathrm{Y}$ & 12,8 & 12,8 & 12,12 & 12,18 \\
$\mathrm{Z}$ & 24,8 & 24,8 & 24,12 & 24,18 \\
\hline
\end{tabular}

Examples for Interpreting the Dividend Tables

Suppose the realized events for $\mathrm{ABC}$ are:

i. $\mathrm{Y}$ in period 1 and $\mathrm{Y}$ in period 2. At the end of period $1 \mathrm{ABC}$ pays a dividend equal to 12 and at the end of period 2 it pays 12 (see cell row $\mathrm{Y}$, column $\mathrm{Y}$ in the $\mathrm{ABC}$ table above (12,12 for period 1 and period 2 respectively)

ii. $\mathrm{Z}$ in period 1 and $\mathrm{X}$ in period 2. At the end of period $1 \mathrm{ABC}$ pays a dividend equal to 24 and at the end of period 2 it pays 12 (see cell row $Z$, column $\mathrm{X}$ in the $\mathrm{ABC}$ table above (24,12 for period 1 and period 2 respectively) 
Suppose the realized events for CRA are:

i. $\quad \mathrm{W}$ in period 1 and $\mathrm{Z}$ in period 2. At the end of period 1 CRA pays a dividend equal to 0 and at the end of period 2 it pays 18 (see cell row $\mathrm{W}$, column $\mathrm{Z}$ above $(0,18$ for period 1 and period 2 respectively)

ii. $\quad Z$ in period 1 and $X$ in period 2. At the end of period 1 CRA pays a dividend equal to 24 and at the end of period 2 it pays 8 (see cell row $Z$, column $X$ above (24,8 for period 1 and period 2 respectively)

\section{Appendix 2 - Study Instrument}

1. Age years

[For Questions 2, 3 and 4 - please circle correct responses]

2. Gender

3. Is English your first language?

4. Have you traded in a share market before? (not including FTS)

5. Confidence in trading with the FTS trading system game

Listed below are activities that could be completed during financial trading with the FTS system. Please indicate how confident you were in performing each activity by circling one number.

If you are not sure of what you did or what the question refers to, please circle the " 0 ".

a) Pricing a share

$\frac{0}{\text { Not sure }}$

b) Setting a bid

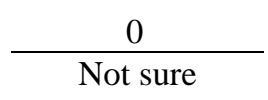

c) Setting an ask

$\frac{0}{\text { Not sure }}$

d) Buying

$\frac{0}{\text { Not sure }}$

e) Selling

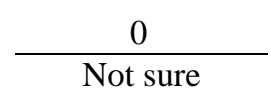

\begin{tabular}{lclcc}
\multicolumn{1}{c}{1} & 2 & \multicolumn{1}{c}{3} & 4 & 5 \\
\hline $\begin{array}{l}\text { Not at all } \\
\text { confident }\end{array}$ & & Moderately & & Totally \\
Confident & & confident
\end{tabular}

\begin{tabular}{lclcc}
1 & 2 & 3 & 4 & 5 \\
\hline $\begin{array}{l}\text { Not at all } \\
\text { confident }\end{array}$ & & Moderately & & Totally \\
Confident & & confident
\end{tabular}

\begin{tabular}{|c|c|c|c|c|}
\hline 1 & 2 & 3 & 4 & 5 \\
\hline $\begin{array}{l}\text { Not at all } \\
\text { confident }\end{array}$ & & $\begin{array}{l}\text { Moderately } \\
\text { Confident }\end{array}$ & & $\begin{array}{c}\text { Totally } \\
\text { confident }\end{array}$ \\
\hline
\end{tabular}


6. FTS experience evaluation

Please indicate how much you agree with each of the following statements as a description of your experience with the FTS trading system game.

a) The FTS game increased my understanding of financial trading.

\begin{tabular}{ccccc}
1 & 2 & 3 & 4 & 5 \\
\hline Totally & & $\begin{array}{c}\text { Neither agree } \\
\text { nor disagree }\end{array}$ & $\begin{array}{l}\text { Totally } \\
\text { agree }\end{array}$
\end{tabular}

b) The FTS game helped me understand the different decisions needed for financial trading.

\begin{tabular}{ccccc}
1 & 2 & 3 & 4 & 5 \\
\hline Totally & & Neither agree & Totally \\
Disagree & & nor disagree & agree
\end{tabular}

c) After the FTS game, I was more satisfied with my understanding of how to trade stocks.

\begin{tabular}{ccccc}
1 & 2 & 3 & 4 & 5 \\
\hline Totally & & Neither agree & Totally \\
Disagree & & nor disagree & agree
\end{tabular}

d) The FTS game gave me practical knowledge of material taught in FINM001.

\begin{tabular}{cccc}
1 & 2 & 3 & 4 \\
\hline Totally & & $\begin{array}{c}\text { Neither agree } \\
\text { nor disagree }\end{array}$ & $\begin{array}{l}\text { Totally } \\
\text { agree }\end{array}$
\end{tabular}

e) Overall, I was satisfied with the experience with the FTS game.

\begin{tabular}{ccccc}
1 & 2 & 3 & 4 & 5 \\
\hline Totally & & Neither agree & Totally \\
Disagree & & nor disagree & agree
\end{tabular}

7. Comment on the use of the FTS trading system game in tutorials and the study

\section{Strategy comments}

Please describe the strategy or strategies that you used during financial trading with FTS. 


\section{Strategies}

For the following questions, please indicate how accurately each of the following statements describes your approach or attempted strategies during financial trading.

If you are not sure of what you did or what the question refers to, please circle the " 0 ".

a) I spent most of my time trying to maximize my earnings

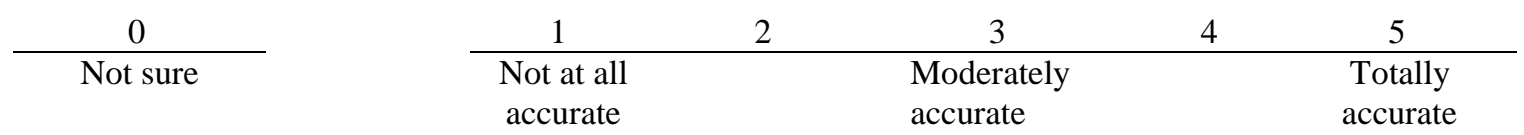

b) I tried to make money through differences in the bid and the ask prices.

\begin{tabular}{|c|c|c|c|c|}
\hline 0 & 1 & 3 & 4 & 5 \\
\hline Not sure & $\begin{array}{l}\text { Not at all } \\
\text { accurate }\end{array}$ & $\begin{array}{l}\text { Moderately } \\
\text { accurate }\end{array}$ & & $\begin{array}{l}\text { Totally } \\
\text { accurate }\end{array}$ \\
\hline
\end{tabular}

c) I tried to make money through differences in the current price of a share and my forecast of future earnings.

\begin{tabular}{ccccc}
0 & 1 & 2 & 3 & 4 \\
\cline { 3 - 6 } Not sure & $\begin{array}{c}\text { Not at all } \\
\text { accurate }\end{array}$ & $\begin{array}{c}\text { Moderately } \\
\text { accurate }\end{array}$ & $\begin{array}{c}\text { Totally } \\
\text { accurate }\end{array}$
\end{tabular}

d) I spent most of my time trying to minimize or avoid losses.

$\frac{0}{\text { Not sure }}$

\begin{tabular}{|c|c|c|c|c|}
\hline 1 & 2 & 3 & 4 & 5 \\
\hline $\begin{array}{l}\text { Not at all } \\
\text { accurate }\end{array}$ & & $\begin{array}{l}\text { Moderately } \\
\text { accurate }\end{array}$ & & $\begin{array}{l}\text { Totally } \\
\text { accurate }\end{array}$ \\
\hline
\end{tabular}

e) I mostly followed a buy and hold strategy.

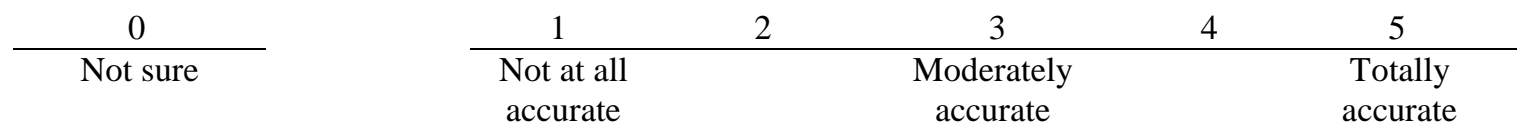

f) I was a very active trader and made a lot of trades in most periods

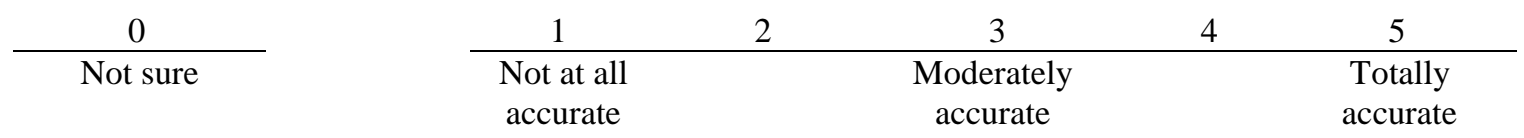

g) I changed my strategies a lot across the different periods.

$\frac{0}{\text { Not sure }}$

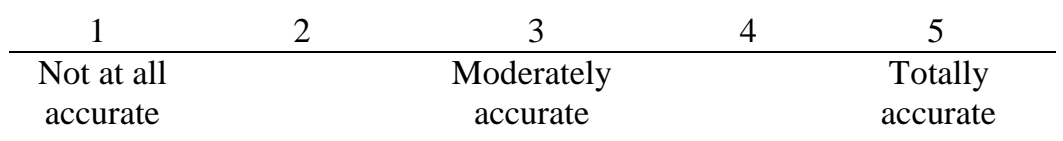




\section{Endnotes}

${ }^{1}$ OS Financial Trading Systems, P.O. Box 11356 Pittsburgh. P.A. 15238, 1800967 9897, email address: fts@ftsweb.com, web address: www.ftsweb.com.

${ }^{1}$ It is also possible to short sell securities and to borrow to fund purchases.

${ }^{1}$ This approach to testing is similar to that used in Helliar, Michaelson, Power and Sinclair (2000).

Notes 


\section{Endnotes}

${ }^{1}$ OS Financial Trading Systems, P.O. Box 11356 Pittsburgh. P.A. 15238, 1800967 9897, email address:

fts@ ftsweb.com, web address: www.ftsweb.com.

${ }^{2}$ It is also possible to short sell securities and to borrow to fund purchases.

${ }^{3}$ This approach to testing is similar to that used in Helliar, Michaelson, Power and Sinclair (2000).

Notes 